\title{
Developmental Changes of the Photochemical Reflectance Index (PRI), Chlorophyll Fluorescence and Leaf Pigments Show the Adaptability of Trees to Local Environments
}

\author{
Hokyung Baek, Unhaing Cho* \\ Department of Biology and Chemistry, Changwon National University, Changwon, Korea \\ Email: *uhcho@changwon.ac.kr
}

How to cite this paper: Baek, H. and Cho, U. (2017) Developmental Changes of the Photochemical Reflectance Index (PRI), Chlorophyll Fluorescence and Leaf Pigments Show the Adaptability of Trees to Local Environments. American Journal of Plant Sciences, 8, 1-13.

http://dx.doi.org/10.4236/ajps.2017.81001

Received: October 27, 2016

Accepted: December 23, 2016

Published: December 26, 2016

Copyright $\odot 2017$ by authors and Scientific Research Publishing Inc. This work is licensed under the Creative Commons Attribution International License (CC BY 4.0).

http://creativecommons.org/licenses/by/4.0/

\begin{abstract}
For plants growing in parks and along the roadsides of a city, the environmental and seasonal regulation of growth, or photosynthesis, is seldom assessed. The phenology of plants may differ due to varying environments, which may result in different growth or adaptability to local environments. Therefore, we explored several assays and optical indicators of photosynthesis and stress in three tree species (Prunus yedoensis Matsum, Zelkova serrata Makino and Acer palmatum Thunb.) and two herbaceous species (Artemisia princeps Pamp and Taraxacum officinale Weber)growing commonly in three local parks of Changwon city, a large industrial city in Korea. The photochemical reflectance index (PRI), chlorophyll fluorescence, and pigments including chlorophyll and the flavonoids of leaves were monitored over a growing season for two years to evaluate the adaptability of plants to local environments. The values of all measurements exhibited striking seasonal and regional changes. PRI values were closely timed with photosynthetic activity and the pigment formation of leaves, particularly in some tree species. For the tree species, the plants which had the low values of PRI during the active growing season showed low levels of both chlorophyll fluorescence and high level of flavonoid, indicating that these plants were experiencing low photosynthetic activity and the specific needs in growth and development were not sufficiently provided by the local environment. Our results indicate that PRI provided a clear optical indicator of plant adaptability to the local environment and may provide a useful metric of effective growth using remote sensing measurements. Furthermore, the periodic PRI measurement is encouraged to be included in the surveillance program for city plant management.
\end{abstract}




\section{Keywords}

Photochemical Reflectance Index, Chlorophyll Fluorescence, Chlorophyll, Flavonoid

\section{Introduction}

Various tree and herbaceous plants are planted in parks, road sides and gardens without a strong knowledge on the relationship between the specific needs of the plants and the local environment. In addition, the physiological status of the plants is seldom analyzed periodically. Furthermore, large cities have been undergoing significant environmental changes, including temperature, moisture, nutrients and air composition. The environmental changes can affect the season length and shift the physiological status, resulting in the alteration of the net primary productivity as a consequence of increased disturbances and environmental stress [1] [2].

Extreme temperatures and drought lead to the down-regulation of photosynthesis, which produces a potential imbalance of light energy capture and usage. Over-excitation of photosystems can cause photodamage to the photosynthetic apparatus, which impairs the leaves ability to photosynthesize [3]. Photoprotective processes involve several changes in photoprotective pigments including carotenoids, which allow the leaves to dissipate excess energy via thermal dissipation in order to maintain an energy balance [4]-[9]. The xanthophyll cycle pigments enable reversible down-regulation of electron transport during conditions of short-term stress [10].

Spectral reflectance measurements of plants have long been used to assess the growth and physiological status of plants in a non-invasive manner [11] [12] [13]. Seasonal pigment changes lead to shifting carotenoid content: chlorophyll ratios that can be detected with spectral reflectance, for example with the derivation of the photochemical reflectance index (PRI), which may serve as an optical indicator of photosynthetic activity [14] [15]. The PRI value depends on the chlorophyll content of the canopy [16]. Chlorophyll fluorescence [17] [18] and light-use efficiency (LUE) [19] [20] are all related to photosynthetic activity. Chlorophyll fluorescence emanates primarily from chlorophyll a in photosystem II [21] and leaf photosynthetic status, as indicated by the chlorophyll pigment content, is also a primary factor in determining leaf reflectance [22].

While previous studies have indicated that the PRI can serve as a useful indicator of the physiological status of plants [19] [23], the exact functional significance of seasonal PRI changes has remained unclear because of the multiple pigments and processes involved, and practical applications have not been tried widely. Obtaining a better understanding of the photosynthetic responses of plants to environmental factors over growing periods is an important challenge for monitoring carbon exchange in city ecosystems.

In this study, we followed the seasonal changes of PRI, chlorophyll fluores- 
cence and pigment formation for several plant species growing commonly in different parks within the city. A primary purpose of this study was to monitor the activity of photosynthesis and stress status by following a variety of physiological parameters at the leaf-level which were used to decide the adaptability of plants to the local environments. The information of this research can be used to establish an effective surveillance program for city plant management.

\section{Materials and Methods}

\subsection{Study Areas and Plant Species}

The study sites are located within Chanwon city, Korea, with three tree species; Yoshino cherry (Prunus yedoensis Matsum), Japanese zelkova (Zelkova serrata Makino) and Japanese maple (Acer palmatum Thunb.) and two herbaceous species; Japanese mugwort (Artemisia princeps Pamp) and dandelion (Taraxacum officinale Weber). These grow commonly in three different parks located at $35^{\circ} 12.358^{\prime} \mathrm{N}$ and $128^{\circ} 41.604^{\prime} \mathrm{E}$ (Gaeumjung park), $35^{\circ} 12.935^{\prime} \mathrm{N}$ and $128^{\circ} 38.807^{\prime} \mathrm{E}$ (Changkok park), and $35^{\circ} 14.333^{\prime} \mathrm{N}$ and $128^{\circ} 40.386^{\prime} \mathrm{E}$ (Bansong park). The investigated trees were 15 - 20 years old and the herbaceous plants were growing naturally. Measurements were made on the third week of every month from April to October 2014 and 2015 on sunny days from 12:00 h to 14:00 h. The healthyappearing mature sunlit leaves from each of the species were selected.

\subsection{Measurement of Spectral Reflectance and PRI Calculation}

Spectral reflectance was measured with a portable spectrophotometer (Konica Minolta CM-700d, Japan) according to the manual provided by the company, and data was analyzed using the SpectraMagic ${ }^{\mathrm{mm}}$ NX program (Ver. 2.0, Konica Minolta, Japan). A total of 10 mature leaves were sampled from each plant and a total five plants of each species from the parks were selected. For all leaf measurements, the mature leaves were selected from canopies exposed to similar light conditions. PRI was calculated as: $\mathrm{PRI}=\left(\mathrm{R}_{531}-\mathrm{R}_{570}\right) /\left(\mathrm{R}_{531}+\mathrm{R}_{570}\right)$. R indicates reflectance, and the subscript indicates the waveband, in $\mathrm{nm}$ [24].

\subsection{Measurements of Chlorophyll Fluorescence}

A total of 10 mature leaves were sampled from each plant and a total five plants of each species from the parks were selected for the measurements of chlorophyll fluorescence using a chlorophyll fluorometer (OS1-FL, Opti-Sciences, USA). The ratio of variable fluorescence $\left(\mathrm{F}_{\mathrm{v}}\right)$ to maximal fluorescence $\left(\mathrm{F}_{\mathrm{m}}\right)$ was calculated as $\mathrm{F}_{\mathrm{v}} / \mathrm{F}_{\mathrm{m}}=\left[\mathrm{F}_{\mathrm{m}}-\mathrm{F}_{\mathrm{o}}\right] / \mathrm{F}_{\mathrm{m}}$. Procedures used for measuring $\mathrm{F}_{\mathrm{v}} / \mathrm{F}_{\mathrm{m}}$ were based on standard methodologies, as documented in the OS1-FL manual.

\subsection{Measurement of Chlorophyll and Flavonoids}

For chlorophyll measurements, leaf discs $(1 \mathrm{~cm}$ diameter) were punctured and $100 \mathrm{mg}$ of the leaf tissues per plant was ground with liquid nitrogen, extracted in $2 \mathrm{ml}$ of $96 \%$ methanol and centrifuged with $2000 \mathrm{~g}$ for 10 minutes. The absor- 
bance of the supernatant was measured with a spectrophotometer (Lamda bio25, Perkin Elmer, UK) and specific absorption coefficients of chlorophyll, reported by Lichtenthaler [25], were used to determine chlorophyll content.

For flavonoids measurements, leaf discs were punctured and $1 \mathrm{~g}$ of the leaf tissue (punches) per plant was ground with liquid nitrogen and extracted in $3 \mathrm{ml}$ of methanol/HCl (99:1, vol:vol) for 12 hours. After adding $2 \mathrm{ml}$ of $\mathrm{H}_{2} \mathrm{Oand} 3 \mathrm{ml}$ of chloroform, the solution was centrifuged with $3000 \mathrm{~g}$ for 2 minutes, and absorbance of the supernatant was measured. A molar absorbance coefficient ( $\varepsilon=$ 31623 ) at $530 \mathrm{~nm}$ was used to calculate flavonoid concentration [26].

\section{Results}

\subsection{PRI}

PRI exhibited seasonal and regional variability for all investigated plant species (Figure 1). The maximum values for trees were observed in the growing season,

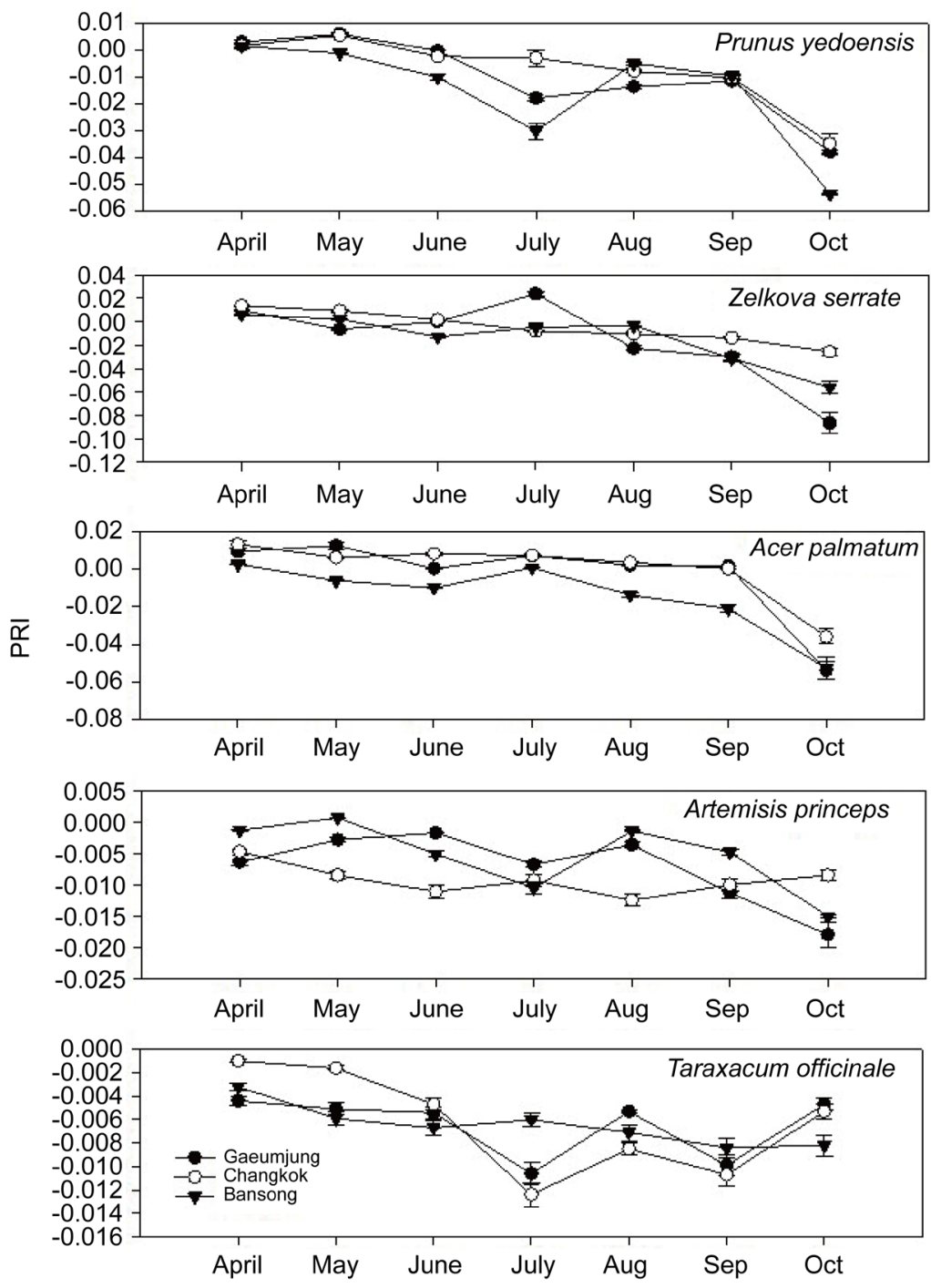

Figure 1. Changes in leaf PRI from plants growing in the three parks of Changwon city monitored in this study. Error bars denote \pm SE of the mean. 
from April to June, and the values gradually decreased by October. However, the values of herbaceous species were relatively stable compared to the trees investigated. The lowest PRI values were observed in the two tree species of $P$. yedoensis and $A$. palmatum growing in Bansongpark compared to the same species in other two parks.

\subsection{Chlorophyll Fluorescence}

The values of chlorophyll fluorescence also exhibited seasonal and regional variability for all species, approximately in parallel with PRI (Figure 2). The values of $P$. yedoensis and $A$. palmatum in Basongpark were always lower than those of the same species in other two parks. A. princeps and T. officinale exhibited no difference in chlorophyll fluorescence among parks.

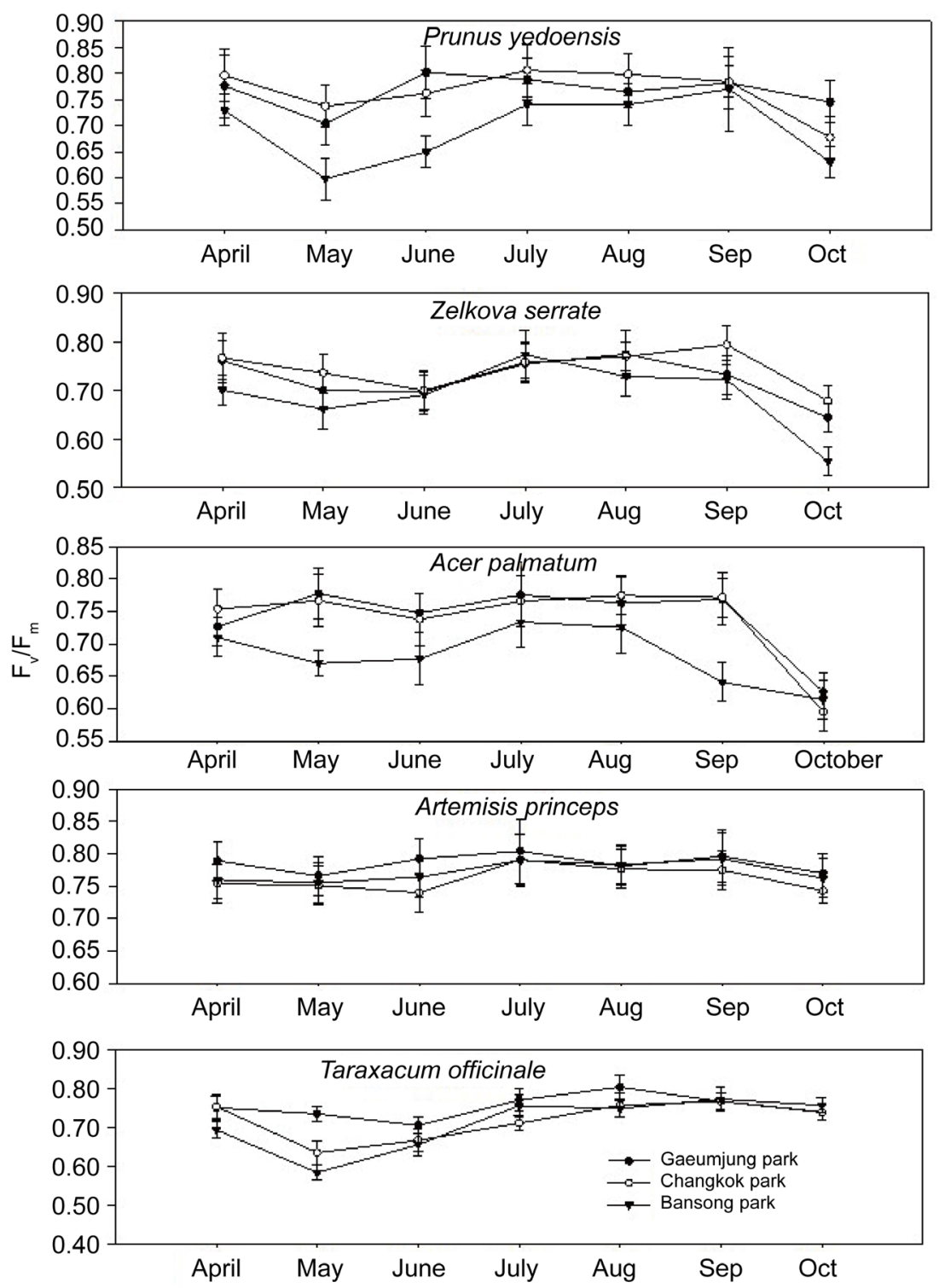

Figure 2. Changes in leaf chlorophyll fluorescence of plants growing in the three parks of Changwon city monitored in this study. Error bars denote \pm SE of the mean. 


\subsection{Chlorophyll and Flavonoid}

The total chlorophyll content of leaves also exhibited seasonal changes that were inversely related to the seasonal PRI patterns in the growing season (Figure 3). Compared to the same species growing in Gaeumjungpark and Changkok park, P. yedoensis and A. palmatum growing in Basong park had the lowest chlorophyll content over the growing season. However, A. princeps and T. officinale exhibited no decrease in chlorophyll content until October, approximately in parallel with PRI and chlorophyll fluorescence.

The value of total flavonoids at leaf-level also changed over the growing season, with different trends among parks (Figure 4). P. yedoensis and A. palmatum,

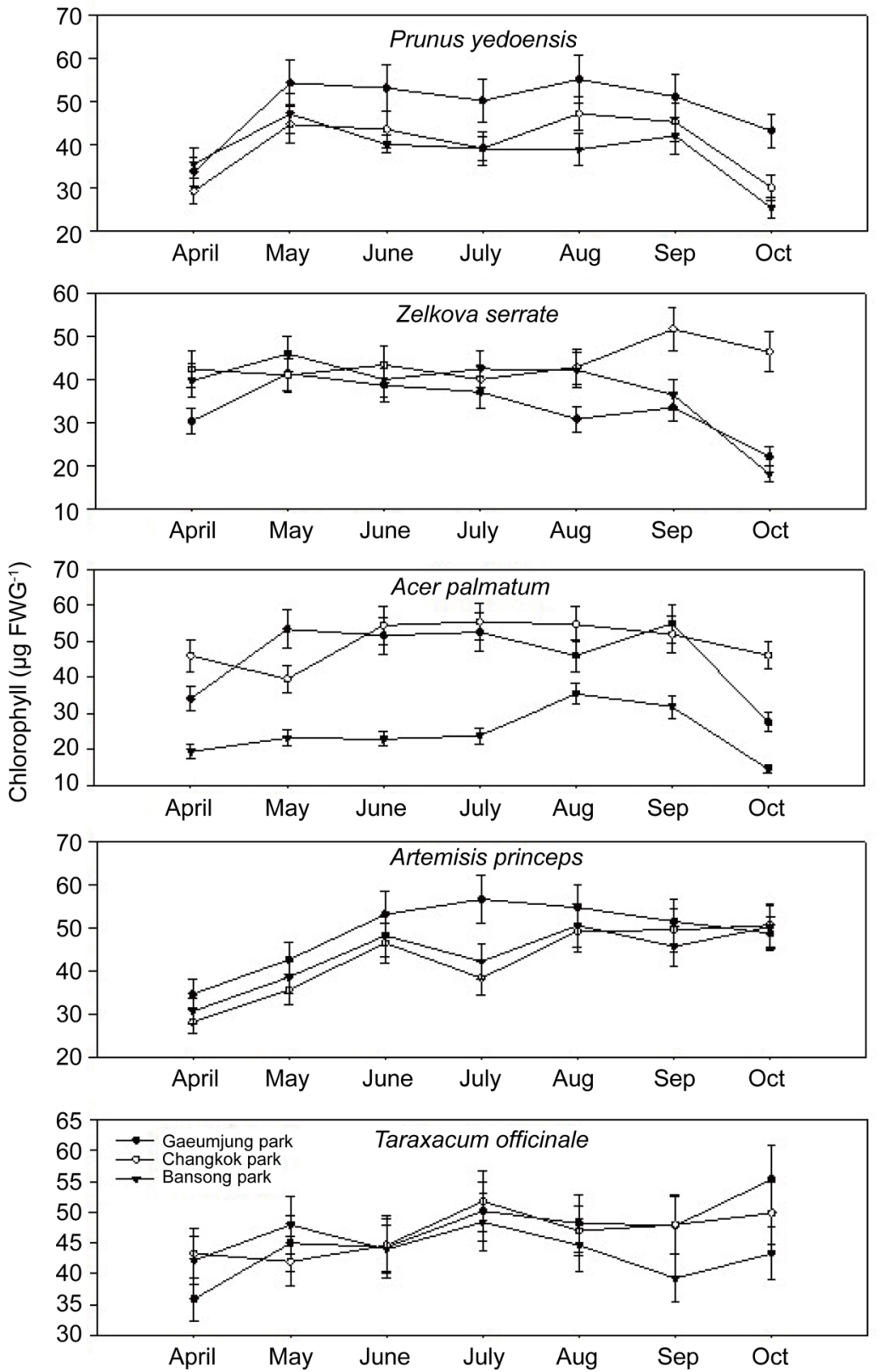

Figure 3. Changes in leaf chlorophyll content of plants growing in the three parks of Changwon city monitored in this study. Error bars denote \pm SE of the mean. 

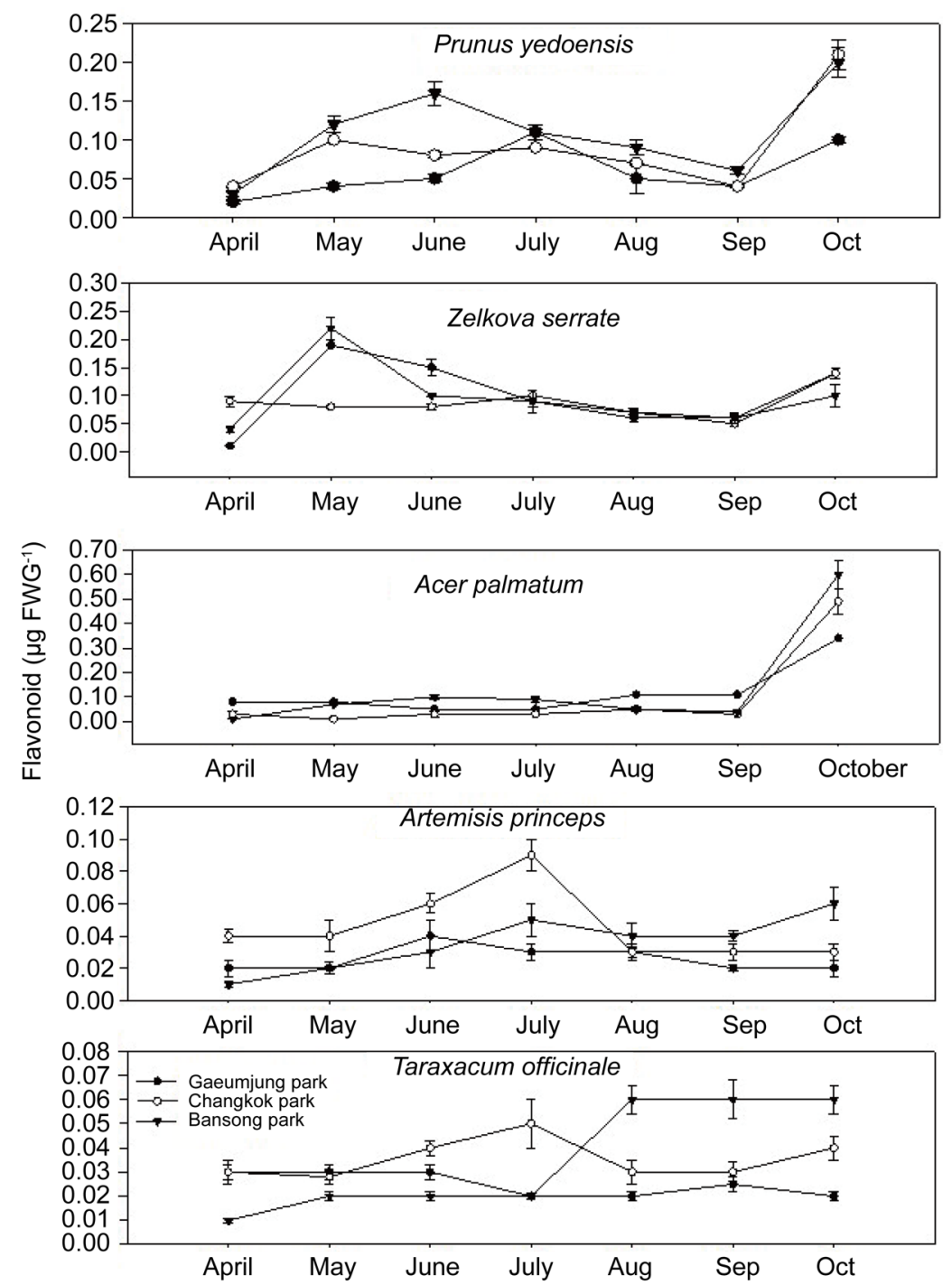

Figure 4. Changes in leaf flavonoid content of plants growing in the three parks of Changwon city monitored in this study. Error bars denote \pm SE of the mean.

in all parks, showed the highest value during fall (October). In spring and summer, the highest value for $P$. yedoensis appeared in June in Bansongpark, in May for Changkok park and July in Gaeumjung park, respectively. The highest value for $Z$. serrata was observed in May for Bansongpark and Gaeumjung park. However, the value for Changkokpark was relatively stable over the growing season. The value of $A$. palmatum in all parks was stable over the growing season. The value of $A$. princeps in Changkokpark showed the highest value on May and was higher than those of the other parks in July. For Bansongpark, the value was higher in summer and fall compared to that of spring. There was only an observed increase in the value in fall for Bansongpark. In T. officinale, the value of Bansongpark was higher in summer and fall, and the value of Changkok park was the highest in July. However, the value of Gauemjungpark was relatively stable over the season. Therefore, the values of all parks showed different trends. The content of flavonoid production may indicate the level of leaf stress 
during the growing season and leaf senescence during fall.

\section{Discussion}

Tree and herbaceous plants are usually planted in parks and along the road sides without the detailed knowledge of their specific needs with respect to growth and development. Furthermore, projected environmental changes in water, nutrient, temperature, $\mathrm{CO}_{2}$, ultraviolet radiation, ozone and pathogens will negatively influence growth and induce an onset of the senescence process, independent of the natural recourse of leaf senescence [27] [28] [29] [30]. Therefore, the analysis or diagnosis of the physiological status of plants is a complex process involving several components that differ with respect to time and kinetics.

\subsection{PRI Difference among Parks}

In this study, PRI showed a variability among species, parks and seasons, indicating that the activation of the xanthophyll cycle and photochemical reactions are the response of plants to various factors of their environments. Based on the PRI trends observed in this study, the trees $P$. yedoensis and $A$. palmatum growing in Bansongpark are experiencing more stress than those growing in other parks (Figure 1). The trees $P$. yedoensis in Bansongpark and $Z$. serrata and A. palmatum in Gaeumjung park and Bansong park are senescing earlier in fall (October). Therefore, for the tree species investigated, it can be concluded that among the three parks, Changkok park is the most optimum in terms of growth. Bansongpark may not be suitable for $P$. yedoensis and $A$. palmatum to grow. Although $A$. princeps in Changkokpark is experiencing more stress over the growing season compared to the other parks, this does not make senescence occur earlier during fall. The plants of the same species in Bansong and Gaeumjung parks are experiencing less stress but are senescing earlier in fall. Although plants of $T$. officinale are experiencing more stress in Gaeumjungpark and Changkok park in July, they are able to maintain high PRI values in October. Therefore, for the herbaceous plants, there is no coordination between PRI, stress and senescence.

\subsection{Interactions between PRI and Chlorophyll Fluorescence}

The pattern of chlorophyll fluorescence of the tree species is very similar to that of PRI (Figure 2). Trees of $P$. yedoensis and A. palmatum (and Z. serrata) in Bansong park maintain lower values compared to the other two parks. This synchrony also suggests that the trees of low PRI value are experiencing low photosynthesis, and Bansongpark is not a suitable place growing compared to the other parks. However, this pattern of chlorophyll fluorescence was not observed for the herbaceous plants. All herbaceous species maintain stable photosynthesis during the period investigated.

\subsection{Interactions between PRI and Pigments}

Leaf chlorophyll content provides valuable information about the physiological 
status of plants [31] [32]. The pattern of chlorophyll change at the leaf-level is similar to that of PRI and chlorophyll fluorescence (Figure 3). The plants of $P$. yedoensis and A. palmatum in Bansongpark showed the lowest chlorophyll content. Z. serrata in Changkokpark maintained the highest chlorophyll content in October, and may indicate the late senescence in this park. For case of the herbaceous plants, $A$. princeps in Bansongpark and Changkok park showed lower chlorophyll content compared to that in Gaeumjung park during growing season. In addition, $T$. officinale in Bansongpark showed lower levels in late summer and fall. For herbaceous plants, chlorophyll content did not show the same trends as PRI and fluorescence. As chlorophyll tends to decline more rapidly than carotenoids when plants are under stress or during leaf senescence [33], the lowered level of PRI observed in some tree species in Bansong park may be induced by a decrease of chlorophyll synthesis.

The change of flavonoids content in leaves indicates the stress and senescence of plants during the growth season. Anthocyanin content tends to be high in young leaves, senescing leaves and leaves of plants where growth has been limited by stresses [34]. The flavonoid contents of $P$. yedoensis and A. palmatunm in Basongpark was high in both June and July (Figure 4). During the same period, PRI and chlorophyll fluorescence were low (Figure 1 and Figure 2), indicating that these plants were in stress. For $P$. yedoensis and $A$. palmatum, the June flavonoids content was negatively related to chlorophyll content (Figure 3 ).

\subsection{Applications of PRI}

Any synchronization between PRI, chlorophyll fluorescence and chlorophyll values (Figures 1-3) shows that PRI most likely detects a pigment size associated with photosynthetic activation. The large PRI variation among the parks provides a clear optical signal that can be detected at leaf-level, showing promising potential for remote detection of PRI transitions over the growing season in different environments in order to diagnosis the physiological status of plants. The PRI figure at the leaf-level indicates the stress experienced by the plant, including the decline of photosynthesis, as indicated by the decrease of chlorophyll fluorescence and chlorophyll content. These results are consistent with previous reports that airborne PRI measurements detect seasonal transitions in photosynthetic LUE in boreal forest stands [19] [35]. The results obtained in this study also support this phenomena, particularly for the tree species. Some tree species not growing well in parks (in this study, Bansongpark) may be due to an inappropriate adaptation to their environment. This inappropriate adaptation might be attributed to specific needs in development and growth. This observation agrees with other studies that showed coincident leaf and stand-level PRI responses for canopy stands [36].

\section{Conclusion}

Consequently, we concluded that the growing pattern and the developmental physiology of a species over the growing season were different among parks stu- 
died in Changwon city, indicating the different adaptability of species to different environments. The response also appeared to be common to all tree species studied, suggesting that it may be a general response of all tree plants exposed to different environment, although further studies on more species are needed to confirm this. However, we caution that additional variations in the PRI signal can arise when monitoring at the ecosystem level because of varying inorganic material in soil, air, water, temperature, canopy structure and illumination. Hence further ecosystem-level studies coupling remote sensing with groundbased measurements of physiology and fluxes during seasonal transitions are warranted. This study helps to clarify the mechanisms of PRI transitions associated with the seasonal photosynthetic activity for tree species. This constitutive PRI response driven primarily by a seasonally changing pigment content could help improve photosynthesis models that make use of remote sensing measurements. If routine observations of PRI seasonal transitions can be included into the city surveillance program for plants, this would provide a potent city monitoring tool for improving city environment standards.

\section{Acknowledgements}

This research was financially supported by Changwon National University in 2015-2016.

\section{References}

[1] Canadell, J.G., Le Quere, C., Raupach, M.R., Field, C.B., Buitenhuis, E.T., Ciais, P., Conway, T.J., Gillett, N.P., Houghton, R.A. and Marland, G. (2007) Contributions to Accelerating Atmospheric $\mathrm{CO}_{2}$ Growth from Economic Activity, Carbon Intensity, and Efficiency of Natural Sinks. Proceedings of the National Academy of Sciences of the United States of America, 104, 18866-18870.

https://doi.org/10.1073/pnas.0702737104

[2] Ciais, P., Reichstein, M., Viovy, N., Granier, A., Ogee, J., Allard, V., Aubinet, M., Buchmann, N., Bernhofer, C. and Carrara, A. (2005) Europe-Wide Reduction in Primary Productivity Caused by the Heat and Drought in 2003. Nature, 437, 529533. https://doi.org/10.1038/nature03972

[3] Powles, S.B. (1984) Photoinhibition of Photosynthesis Induced by Visible Light. Annual Review of Plant Physiology and Plant Molecular Biology, 35, 15-44. https://doi.org/10.1146/annurev.pp.35.060184.000311

[4] Butler, W.L. (1978) Energy Distribution in Photochemical Apparatus of Photosynthesis. Annual Review of Plant Physiology and Plant Molecular Biology, 29, 345378. https://doi.org/10.1146/annurev.pp.29.060178.002021

[5] Baker, N.R. (2008) Chlorophyll Fluorescence: A Probe of Photosynthesis in Vivo. Annual Review of Plant Biology, 59, 89-113. https://doi.org/10.1146/annurev.arplant.59.032607.092759

[6] Holzwarth, A.R., Miloslavina, Y., Nilkens, M. and Jahns, P. (2009) Identification of Two Quenching Sites Active in the Regulation of Photosynthetic Light-Harvesting Studied by Time-Resolved Fluorescence. Chemical Physics Letters, 483, 262-267. https://doi.org/10.1016/j.cplett.2009.10.085

[7] Ruban, A.V., Johnson, M.P. and Duffy, C.D.P. (2012) The Photoprotective Molecular Switch in the Photosystem II Antenna. Biochimica et Biophysica Acta-Bioener- 
getics, 1817, 167-181. https://doi.org/10.1016/j.bbabio.2011.04.007

[8] Verhoeven, A. (2014) Sustained Energy Dissipation in Winter Evergreens. New Phytologist, 201, 57-65. https://doi.org/10.1111/nph.12466

[9] Frechette, E., Wong, C.T.Y., Junker, L.V., Chang, C.Y.Y. and Ensminger, I. (2015) Zeaxanthin-Independent Energy Quenching and Alternative Electron Sinks Cause Decoupling of the Relationship between the Photochemical Reflectance Index (PRI) and Photosynthesis in an Evergreen Conifer during Spring. Journal of Experimental Botany, 66, 7309-7323. https://doi.org/10.1093/jxb/erv427

[10] Demmig-Adams, B. and Adams, W.W. (1992) Photoprotection and Other Responses of Plants to High Light Stress. Annual Review of Plant Physiology and Plant Molecular Biology, 43, 599-626.

https://doi.org/10.1146/annurev.pp.43.060192.003123

[11] Sims, D.A. and Gamon, J.A. (2002) Relationships between Leaf Pigment Content and Spectral Reflectance across a Wide Range of Species, Leaf Structures and Developmental Stages. Remote Sensing of Environment, 81, 337-354.

https://doi.org/10.1016/S0034-4257(02)00010-X

[12] Vollsnes, A.V., Melo, T.B. and Futsaether, C.M. (2012) Photomorphogenesis and Pigment Induction in Lentil Seedling Roots Exposed to Low Light Conditions. Plant Biology, 14, 467-474. https://doi.org/10.1111/j.1438-8677.2011.00516.x

[13] Ollinger, S., Reich, P.B., Frolking, S., Lepine, L.C., Hollinger, D.Y. and Richardson, A.D. (2013) Nitrogen Cycling, Forest Canopy Reflectance, and Emergent Properties of Ecosystems. Proceedings of the National Academy of Sciences of the United States of America, 110, E2437. https://doi.org/10.1073/pnas.1304176110

[14] Wong, C.Y.S. and Gamon, J.A. (2015) The Photochemical Reflectance Index Provides an Optical Indicator of Spring Photosynthetic Activation in Evergreen Conifers. New Phytologist, 206, 196-208. https://doi.org/10.1111/nph.13251

[15] Wong, C.Y.S. and Gamon, J.A. (2015) Three Causes of Variation in the Photochemical Reflectance Index (PRI) in Evergreen Conifers. New Phytologist, 206, 187-195. https://doi.org/10.1111/nph.13159

[16] Merlier, E., Hmimina, G., Duftrene, E. and Soudani, K. (2015) Explaining the Variability of the Photochemical Reflectance Index (PRI) at the Canopy-Scale: Disentangling the Effects of Phenological and Physiological Changes. Journal of Photochemistry and Photobiology B: Biology, 151, 161-171. https://doi.org/10.1016/j.jphotobiol.2015.08.006

[17] Maxwell, K. and Johnson, G.N. (2000) Chlorophyll Fluorescence-A Practical Guide. Journal of Experimental Botany, 51, 659-668.

https://doi.org/10.1093/jexbot/51.345.659

[18] Porcar-Castell, A. (2011) A High-Resolution Portrait of the Annual Dynamics of Photochemical and Non-Photochemical Quenching in Needles of Pinus sylvestris. Physiologia Plantarum, 143, 139-153. https://doi.org/10.1111/j.1399-3054.2011.01488.x

[19] Nichol, C.J., Lloyd, J., Shibistova, O., Arneth, A., Roser, C., Knohl, A., Matsubara, S. and Grace, J. (2002) Remote Sensing of Photosynthetic-Light-Use Efficiency of a Siberian Boreal Forest. Tellus Series B: Chemical and Physical Meteorology, 54, 677-687. https://doi.org/10.1034/j.1600-0889.2002.01347.x

[20] Porcar-Castell, A., Garcia-Plazaola, J.I., Nichol, C.J., Kolari, P., Olascoaga, B., Kuusinen. N., Fernandez-Marın, B., Pulkkinen, M., Juurola, E. and Nikinmaa, E. (2012) Physiology of the Seasonal Relationship between the Photochemical Reflectance Index and Photosynthetic Light Use Efficiency. Oecologia, 170, 313-323.

https://doi.org/10.1007/s00442-012-2317-9 
[21] Schreber, U., Bilger, W. and Neubauer, C. (1994) Chlorophyll Fluorescence as a Non-Destructive Indicator for Rapid Assessment of in Vivo Photosynthesis. Ecological Studies, 71, 49-70.

[22] Jacquemoud, S., Ustin, S.L., Verdebout, J., Schmuck, G., Andreoli, G. and Hosgood, B. (1996) Estimating Leaf Biochemistry Using the Prospect Leaf Optical Properties Model. Remote Sensing of Environment, 56, 194-202. https://doi.org/10.1016/0034-4257(95)00238-3

[23] Filella, I., Porcar-Castell, A., Munne-Bosch, S., B€ack, J., Garbulsky, M.F. and Penuelas, J. (2009) PRI Assessment of Long-Term Changes in Carotenoids/Chlorophyll Ratio and Short-Term Changes in De-Epoxidation State of the Xanthophyll Cycle. International Journal of Remote Sensing, 30, 4443-4455. https://doi.org/10.1080/01431160802575661

[24] Gamon, J.A. and Serrano, L. and Surfus, J.S. (1997) The Photochemical Reflectance Index: An Optical Indicator of Photosynthetic Radiation Use Efficiency across Species, Functional Types, and Nutrient Levels. Oecologia, 112, 492-501. https://doi.org/10.1007/s004420050337

[25] Lichtenhaler, H.K., Gitelson, A.A. and Lang, M. (1996) Non-Destructive Determination of Chlorophyll Content of Leaves of a Green and an Aurea Mutant of Tobacco by Reflectance Measurements. Journal of Plant Physiology, 148, 483-493. https://doi.org/10.1016/S0176-1617(96)80283-5

[26] Chatterjee, M., Sharma, P. and Khurana, J.P. (2006) Cryptochrome 1 from Brassica napus Is Up-Regulated by Blue Light and Controls Hypocotyl/Stem Growth and Anthocyanin Accumulation. Plant Physiology, 141, 61-74. https://doi.org/10.1104/pp.105.076323

[27] Curran, P.J., Dungan, J.L. and Peterson, D.L. (2001) Estimating the Foliar Biochemical Concentration of Leaf with Reflectance Spectrometry: Testing the Kokaly and Clark Methodologies. Remote Sensing of Environment, 76, 349-359. https://doi.org/10.1016/S0034-4257(01)00182-1

[28] Stone, C., Chisholm, L. and Coops, N. (2001) Spectral Reflectance Characteristics of Eucalypt Foliage Damaged by Insects. Australian Journal of Botany, 49, 687-698. https://doi.org/10.1071/BT00091

[29] Munne-Bosch, S., Jubany-Mari, T. and Alegre, L. (2001) Drought Induced Senescence Is Characterized by a Loss of Antioxidant Defenses in Chloroplasts. Plant Cell Environment, 24, 1319-1327. https://doi.org/10.1046/j.1365-3040.2001.00794.x

[30] Gray, S.B., Dermody, O. and Delucia, E.H. (2010) Spectral Reflectance from a Soybean Canopy Exposed to Elevated $\mathrm{CO}_{2}$ and $\mathrm{O}_{3}$. Journal of Experimental Botany, 61, 4413-4422. https://doi.org/10.1093/jxb/erq244

[31] Carter, G.A. and Knapp, A.K. (2001) Leaf Optical Properties in Higher Plants: Linking Spectral Characteristics to Stress and Chlorophyll Concentration. American Journal of Botany, 88, 677-684. https://doi.org/10.2307/2657068

[32] Gitelson, A.A., Gritz, Y. and Merzlyak, M.N. (2003) Relationship between Leaf Chlorophyll Content and Spectral Reflectance and Algorithms for Non-Destructive Chlorophyll Assessment in Higher Plant Leaves. Journal of Plant Physiology, 160, 271-282. https://doi.org/10.1078/0176-1617-00887

[33] Merzlyak, M.N., Gitelson, A.A., Chivkunova, O.B. and Rakitin, V.Y. (1999) NonDestructive Optical Detection of Pigment Changes during Leaf Senescence and Fruit Ripening. Physiologia Plantarum, 106, 135-141. https://doi.org/10.1034/j.1399-3054.1999.106119.x

[34] Chalker-Scott, L. (1999) Environmental Significance of Anthocyanins in Plant Stress Responses. Photochemistry and Photobiology, 70, 1-9. 
https://doi.org/10.1111/j.1751-1097.1999.tb01944.x

[35] Gamon, J.A. and Qiu, H. (1999) Ecological Applications of Remote Sensing at Multiple Scales. In: Pugnaire, F.I. and Valladares, F., Eds., Handbook of functional plant ecology, Marcel Dekker, New York, 805-846.

[36] Nichol, C.J., Huemmrich, K.F., Black, T.A., Jarvis, P.G., Walthalll, C.L., Grace, J. and Hall, F.G. (2000) Remote Sensing of Photosynthetic-Light-Use Efficiency of Boreal Forest. Agricultural and Forest Meteorology, 101, 131-142.

https://doi.org/10.1016/S0168-1923(99)00167-7

Submit or recommend next manuscript to SCIRP and we will provide best service for you:

Accepting pre-submission inquiries through Email, Facebook, LinkedIn, Twitter, etc. A wide selection of journals (inclusive of 9 subjects, more than 200 journals)

Providing 24-hour high-quality service

User-friendly online submission system

Fair and swift peer-review system

Efficient typesetting and proofreading procedure

Display of the result of downloads and visits, as well as the number of cited articles

Maximum dissemination of your research work

Submit your manuscript at: http://papersubmission.scirp.org/

Or contact ajps@scirp.org 